\title{
Mannen met een hobby
}

\section{Outlaw motorclubs, nieuwsmedia en imagopolitiek}

\author{
Willem Koetsenruijter \& Peter Burger
}

\begin{abstract}
Dit onderzoek is een kwalitatieve framinganalyse van de mediarepresentatie van outlaw motorclubs in Nederlandse nieuwsberichten. De analyse laat zien dat de groep zelf als bron voor positieve framing in de media fungeert en zo een tegenwicht biedt aan het gangbare georganiseerde-misdaadframe. Het onderzoek laat zien met welke retorische middelen, aangereikt door clubleden, de nieuwsmedia het counterframe 'mannen met een hobby' vormgeven. De berichtgeving over de motorclubs balanceert tussen een crimineel en een niet-crimineel imago, onder andere met een beroep op ethische normen en groepswaarden en met mitigatiestragieën die het frame afzwakken en tegelijkertijd de geloofwaardigheid van de leden vergroten.
\end{abstract}

\section{Inleiding}

Outlaw motorclubs ${ }^{1}$ zijn een gewild onderwerp in nieuwsmedia. Niet alleen gerenommeerde dagbladen, maar ook weekbladen als Nieuwe Revu en Panorama besteden er op gezette tijden aandacht aan. Diverse misdaadjournalisten schreven er boeken over (bijvoorbeeld Schutten e.a., 2004; Van den Heuvel \& Huisjes, 2009). Alleen al in 2014 verschenen in Nederlandse dagbladen meer dan 2.300 artikelen over outlaw motorclubs. Over de hoeveelheid media-aandacht heeft deze groep dus niet te klagen.

De leden van motorclubs worden in nieuwsmedia in verband gebracht met afpersing, verstoring van de openbare orde, geweld, wapenbezit, vrouwenhandel en moord. Het Openbaar Ministerie (OM) is er tot op heden echter niet in geslaagd om een club als criminele organisatie veroordeeld te krijgen. OM en politie zijn in het algemeen en ook in dit geval belangrijke bronnen voor (misdaad)journalisten. Anders dan bij de meeste andere vormen van criminaliteit echter, zijn ook de vermeende criminelen een voorname nieuwsbron.

Waar de meeste criminele groepen proberen onder de radar te blijven, zijn outlaw motorclubs geneigd zich uitdrukkelijk te presenteren in het openbare leven. Uiterlijk vertoon is onderdeel van de groepscultuur en publiciteit is daarbij een belangrijk middel. De relatie met de pers is een dubbele: als de aandacht zich alleen richt op criminele activiteiten als drugshandel en geweld, wordt het open-

1 De gangbare in onderzoek gehanteerde Engelse term is outlaw motor gang (OMG). Anderen gebruiken de term 1\%-motorclubs of -gangs. Wij hebben hier gekozen voor de term 'outlaw motorclub', die onzes inziens beter het spectrum afdekt dat loopt van de radicale tot de meer conservatieve clubs, waarbij die laatste clubleden zich vooral voelen aangetrokken tot de mentaliteit en de sfeer binnen de club, terwijl radicalen diep betrokken zijn bij criminaliteit (Barker, 2007; Wolf, 1991; Lowe, 1988). 
baar voortbestaan van de groep gecompliceerd, als de aandacht zich alleen richt op de kenmerken die de club als een gewone motorclub karakteriseren, kan de club zich niet als outlaw motorclub kenbaar maken en de groepswaarden uitdragen. Die dubbele moraal vergt zorgvuldig balanceren.

De clubs zijn daarbij niet alleen onderwerp van media-aandacht: ze hebben ook een eigen stem en genereren zelf actief media-aandacht. De Facebookpagina 'Discriminatie van motorclubs' is grotendeels gewijd aan het bestrijden van negatieve beeldvorming. Ook lijken clubs of clubleden nieuwsmedia zelf te benaderen, bijvoorbeeld door journalisten uit te nodigen voor 'een kijkje in het clubhuis' en regelmatig ruimte te vragen voor 'het eigen verhaal'. Zo organiseerde No Surrender-captain Henk Kuipers in juni 2017 een persconferentie met als aangekondigd onderwerp 'de negatieve beeldvorming in de media met betrekking tot motorclubs in het algemeen en No Surrender in het bijzonder' (RTV Drenthe, 7 juni 2017). Het is aannemelijk dat leden van motorbendes zo invloed pogen uit te oefenen op de manier waarop ze geframed worden in het nieuws.

Studies naar de verhoudingen tussen outlaw motorclubs en media zijn schaars, en op een enkele uitzondering na (Andersen \& Krumsvik, 2017, over Noorse bikers) hebben de meeste betrekking op Noord-Amerika (Lyng \& Bracey, 1995; Fuglsang, 2003; Katz, 2011). Zij benaderen de labeling door rechtshandhavers kritisch; Katz (2011) spreekt in haar onderzoek naar een Canadese bendeoorlog van een morele paniek. Bij het ontstaan hiervan zijn volgens haar drie actoren betrokken: politici, publiek en media. Opvallend genoeg plaatst zij de clubs zelf uitdrukkelijk buiten deze driehoek (p. 236). Hoewel ze ook stelt dat de clubs niet zonder stem zijn (p. 239) en bijvoorbeeld hun imago opschonen door zorgvuldig georkestreerde toy runs (manifestaties waarbij motorrijders speelgoed aanbieden aan bijvoorbeeld een kinderziekenhuis), gaat Katz verder voorbij aan het mediaoptreden van clubleden. Juist op dat mediaoptreden richt dit onderzoek zich, door krantenartikelen te analyseren waarin leden van outlaw motorclubs aan het woord komen.

De vraag die we met dit onderzoek willen beantwoorden, is op welke manier outlaw motorclubs gepresenteerd worden in het nieuws en zichzelf presenteren. Deze vraag is op verschillende manieren theoretisch en methodologisch in te kaderen. Wij kiezen er hier voor aan te sluiten bij Cohens theorie over folk devils (Cohen, 2002), aangevuld met inzichten over impressiemanagement (Goffman, 1959), en laten ons methodologisch en theoretisch sturen door theorie over nieuwsframing. Hierna zetten we die uitgangspunten nader uiteen.

\section{Theoretisch kader}

In onze optiek is het media-imago van organisaties zoals outlaw motorclubs het veranderlijke resultaat van de inspanningen van drie partijen: politie en justitie, de leden en woordvoerders (soms hun advocaten) van motorclubs en nieuwsmedia. In tegenstelling tot Katz delen we het publiek of de nieuwsconsument een kleine rol toe als toeschouwer en beschouwen we de rol van de (Nederlandse) politiek als zeer beperkt; politici komen in het geanalyseerde tekstmateriaal weinig aan het woord. Uit eerder onderzoek naar misdaadnieuws blijkt dat journalisten 
bij de constructie van criminaliteit een essentiële maar overwegend volgende rol vervullen als 'secondary definers' (Schlesinger \& Tumber, 1994), dat politie en justitie in het algemeen leidend zijn, maar dat criminele of gecriminaliseerde personen en partijen zeker niet machteloos zijn (McRobbie, 1994). Als onderzoekers van journalistiek benaderen wij deze krachtmeting vooral vanuit de framinganalyse en retorica. Voor de achterliggende verklaring zoeken we aansluiting bij criminologisch onderzoek naar morele paniek en naar crimineel impressiemanagement.

De rol die motorbendes lijken te spelen in het framingproces kan verhelderd worden aan de hand van Cohens klassieke studie uit 1972 Folk devils and moral panics (2002). Als marginale groep passen leden van criminele motorclubs in de verzameling deviante en delinquente subculturen van Cohen, die ook zelf de Hells Angels noemt (p. 1). Hoewel ze te oud zijn voor het predicaat jeugdbende (Blokland e.a., 2017), kenmerken leden van outlaw motorclubs zich door een afwijkend uiterlijk en gewelddadig gedrag. Ze lijken dus geknipt voor de rol van folk devils, 'visible reminders of what we should not be' (Cohen, 2002, 2; Fuglsang, 2003, 192-193).

Cohen en andere vroege auteurs op het gebied van moral panics voerden deze folk devils op als min of meer krachteloze slachtoffers van beeldvorming door de maatschappelijke elite en massamedia. Latere studies kennen hun meer agency toe en hebben meer oog voor de publiciteitsmiddelen waarover zij zelf beschikken (McRobbie \& Thornton, 1995) en voor de wisselwerking tussen mediabeelden en het gedrag van de folk devils (Lyng \& Bracey, 1995, 249). In 'Folk devils fight back' betoogt McRobbie (1994) dat gemarginaliseerde groepen zich hadden georganiseerd en in de massamedia en in eigen media weerwerk boden tegen het dominante vertoog. Ook wanneer de folk devils zelf tot de elite behoorden, een categorie waarvoor Cohen in 1972 nog geen aandacht had, zoals in het geval van 'graaiende' bankiers en 'pedopriesters', spelen zij een actieve rol in de manier waarop ze door de nieuwsmedia geframed worden (Jenkins, 1995, 2001; Kreemers, 2011; Koetsenruijter \& Burger, 2017).

Een andere correctie op het moral panic-model van Cohen is de erkenning dat media en folk devils elkaar wederzijds beïnvloeden. Culturele criminologen richtten de blik op een wereld waarin 'the street scripts the screen and the screen scripts the street' (Hayward \& Young, 2004, 259). Een van de uitgangspunten van culturele criminologie is dat in de laatmoderne periode de grens tussen daad en representatie vervaagt: 'echte' personen en hun handelingen kunnen niet of nauwelijks meer onderscheiden worden van hun mediarepresentaties, zodat criminelen aan ons verschijnen als gemediatiseerde beelden in een oneindige spiegelzaal (Ferrell \& Sanders, 1995, 14).

Criminelen werken aan hun publieke imago, onder meer door via nieuwsmedia gunstige publiciteit te genereren. Ze doen aan impressiemanagement (Goffman, 1959) om persoonlijke doelen te bereiken, een consistent beeld van zichzelf neer te zetten en bepaalde sociale normen te bevestigen. In termen van Goffman is dit gedrag in de media 'front stage'-gedrag, een theaterperformance voor buitenstaanders. Het grootste deel van de studies naar motorbendes heeft betrekking op dit theater. Ook de tv-documentaires die pretenderen een blik achter de scher- 
men te geven, hebben doorgaans de goedkeuring van de clubleden, zodat we een zorgvuldig georkestreerd narratief krijgen voorgeschoteld. ${ }^{2}$

Op het toneel, front stage, zet de club een beeld neer dat afwijkt van het beeld dat het OM naar buiten brengt via de pers. Clubs zoeken daarvoor geregeld zelf de media op om reputatieschade te beperken. In zijn etnografische studie van de Haagse Crips, vooral van hun voorman Keylow, benadrukt Roks (Roks \& Staring, 2008; Roks, 2016) dat Keylows talrijke optredens in kranten, tijdschriften en op tv performances waren, waarbij hij strategisch verschillende identiteiten liet zien. Als gangstarapper zette hij afwisselend zijn identiteit als badass ganglid en die van rapper in het spotlicht. Hij kwam ervoor uit dat hij geweld niet schuwde, maar het 'niet zomaar' gebruikte. Tegelijkertijd wil hij via de media aan politie en justitie duidelijk maken dat de Crips hun aandacht niet verdienen (Roks \& Staring, 2008, 170-171). De etnografische studie van Roks laat zien dat de retorische strategieën niet noodzakelijk het gewenste effect hebben. Keylow bespeelt de media, maar heeft ze niet volledig onder controle: als hij wil kiezen voor een 'muzikale, legitieme identiteit', blijven media de oude 'deviante, gewelddadige en criminele identiteit' reproduceren (p. 171-172).

Uit de literatuur over 'sociale bandieten' (Hobsbawm, 1971, 1972), ofwel 'criminele helden' (Kooistra, 1989; Lanjouw \& Burger, 2013) blijkt dat deze combinatie van groepscultuur, afkeer van autoriteiten en gerechtvaardigd geweld een beproefd recept is in impressiemanagement door criminelen. Dat dit imago ook een groot niet-crimineel publiek kan aanspreken, blijkt onder meer uit een van de grootste verkoopsuccessen uit de Nederlandse misdaadverslaggeving, De zaak Heineken (1983), door Peter R. de Vries (Lanjouw \& Burger, 2013).

Het imagowerk dat wij beschrijven, vertoont ook overeenkomsten met het vijftal neutralisatietechnieken uit het klassieke artikel van Sykes en Matza (1957), met name met de vierde en vijfde, de veroordeling van de veroordelaars (politie en justitie zijn zelf onrechtvaardig) en het beroep op hogere loyaliteiten (clubleden zijn verbonden door een erecode, die belangrijker is dan de wet). Het verschil is dat de jeugdcriminelen die Sykes en Matza beschrijven, zich vooral verontschuldigen voor crimineel gedrag; de positieve framing door motorclubs heeft tot doel een gunstig imago te scheppen, dat beschuldigingen bij voorbaat ontkracht.

De botsing tussen het beeld dat motorclubs van zichzelf willen creëren en het beeld van politie en justitie is te analyseren als een strijd tussen frames. Frames zijn begripssjablonen, 'kleine, onuitgesproken theorietjes' (Gitlin, 1980, 6-7), die deel uitmaken van het culturele repertoire. Onuitgesproken omdat frames analytische constructies zijn, die doorgaans niet in die letterlijke vorm compleet in de mediateksten zijn terug te vinden. Ze belichten het ene en verdoezelen het andere met als doel een specifieke interpretatie te prononceren. Het is belangrijk te benadrukken dat frames ons niets vertellen over de statistische werkelijkheid achter het verschijnsel, maar meer over de manier waarop media erover berichten. Fra-

2 In dit opzicht is bewonderenswaardig werk gedaan door Beare en Hogg (2013), die door tapverslagen van straatbendes te gebruiken in staat waren om communicatie tussen leden te analyseren die niet werd beïnvloed door de aanwezigheid van een journalist of camera. 
mes kunnen bewust worden ingezet als middelen om een debat te beïnvloeden en worden door media onderling vaak onbewust van elkaar overgenomen. De partijen die de frames in de markt zetten of in het nieuws brengen, worden framesponsors genoemd (Van Gorp, 2007, 16).

Achterliggend idee van framingtheorie is dat nieuwsfeiten geen afspiegeling van de werkelijkheid zijn, maar constructen die in principe op eindeloos veel manieren kunnen worden vormgegeven. Daarbij worden door de keuze van feiten, formuleringen en beeld altijd bepaalde aspecten van het onderwerp benadrukt en andere weggedrukt. Framing is daarmee niet een specifieke eigenschap van een mediaboodschap, maar een theoretische bril om naar die werkelijkheid te kijken.

De kracht van framing is dat het noemen van een van de onderdelen ('cellen') uit het frame het complete frame kan activeren. Zo is het noemen van de combinatie 'tsunami' en 'vluchtelingen' voldoende om een specifiek frame over de vluchtelingenproblematiek te triggeren (Entman, 1993; Van Gorp, 2005, 2006; De Vreese, 2005).

Resultaat van een kwalitatieve framinganalyse is doorgaans een beperkt aantal frames dat inzicht biedt in de meest saillante manieren waarop het discours gevoerd wordt. Daarmee is zo'n analyse niet allesomvattend of alles afdekkend, maar een voor het doel relevante en inzicht biedende vereenvoudiging van het discours:

'De vraag of de waaier aan frames die de codeerprocedure opleverde de juiste is en of deze exhaustief is, moet daarom anders worden geformuleerd. (...) De juistheid van de frames wordt gemeten aan de hand van het functionele karakter en het verklarende potentieel van de frames.' (Van Gorp, 2006, 107)

Verschillende partijen - framesponsors - kunnen in nieuwsmedia frames tegenover elkaar stellen. Zo zullen we in het geval van de mediarepresentatie van motorbendes zien dat tegenover het criminaliserende frame van justitie, motorclubs een eigen counterframe in stelling brengen. Bij het in stelling brengen van een counterframe zijn twee wegen mogelijk (Van Gorp \& Vercruysse, 2012): een alternatief frame dat naar elementen van het dominante frame verwijst en deze poogt te ontkrachten, of een zelfstandig, positief frame, dat niet refereert aan het dominante frame. De laatste optie is effectiever, omdat een autonoom frame niet het negatieve frame activeert bij het publiek.

\section{Mediarepresentatie van motorbendes}

Over de framing van bikers in de VS bereiken twee publicaties uit 2003 frappant uiteenlopende conclusies. Volgens Wood (2003) is het beeld van de clubs lange tijd omgeven met een mix van romantische ideeën over vrijheid, anarchie, nonconformisme, antioverheid en anti-establishment. Wood noemt uit die tijd de term 'motorized hippies' (p. 336). Het omslagpunt naar een negatief frame kwam volgens hem in 1969, na het geruchtmakende Stones-concert in Altamont, waar- 
bij een Hells Angel die deel uitmaakte van de beveiliging van de band een man doodstak.

Fuglsang (2003) daarentegen beschrijft een folk devils-frame, dat omstreeks 1988 vervangen wordt door een positiever rebellenframe. Hij schetst de uiterlijke kenmerken van het klassieke frame waarmee motorclubs in de nieuwsmedia geportretteerd worden: mannen met een 'badass attitude', zwart lederen jacks, zware boots en spijkerbroeken (p. 185). Dat imago is afkomstig uit de tweede helft van de twintigste eeuw, toen de eerste bendes in de VS en Canada ontstonden. Ook populaire cultuur heeft een belangrijke bijdrage geleverd aan deze beeldvorming, onder meer in talloze populaire boeken over motorclubs, waarvan het bekendste misschien wel dat van Sonny Barger is, de langstzittende captain van de Amerikaanse Hells Angels. Hij beschreef de club als een groep mannen die houden van plezier maken, een beetje knokken nu en dan, vrouwen en af en toe wat drugs (Barger, 2001). Maar ook in klassieke films zien we dit beeld terug, zoals in The Wild One of Easy Rider. En meer recent in de Netflix-serie Sons of Anarchy, waarin een fictionele outlaw motorgang figureert (Castleberry, 2014).

Fuglsang (2003) laat zien hoe nieuwsmedia reageerden ten tijde van de opkomst van de motorclubs. Media gebruikten, zo zegt hij, vaste mythen, beelden en metaforen om het verschijnsel betekenis te geven. Volgens hem namen media de gelegenheid te baat om de behoefte van het publiek aan sensatie in te lossen. Clubleden werden voorgesteld als 'niet-burgers' en daarmee werden tegelijkertijd de piketpaaltjes geslagen van de jarenzestig-middenklassenormen van beschaafd gedrag. Leden van motorclubs vormden volgens hem een voorbeeld van wat er mis was met de samenleving en een symbool van sociale en seksuele deviantie. En elke keer dat er weer een motorrijder voor een vergrijp werd opgebracht, vormde die een 'miniatuurlesje in goed burgerschap' (p. 185, 192). Pas vanaf het eind van de jaren tachtig portretteerden Amerikaanse mainstreammedia volgens Fuglsang bikers als vrijheidslievende rebellen en succesvolle zakenmensen (p. 193).

Zowel Wood als Fuglsang verantwoordt niet op basis van welk materiaal en welke methode zij tot hun tegenstrijdige conclusies komen. Het type analyse noch het gehanteerde materiaal wordt expliciet verwoord. In de voorliggende studie naar mediarepresentatie van motorbendes stellen we een meer gestructureerde aanpak voor, gebaseerd op ideeën over framinganalyse van Entman (1993), Van Gorp (2005, 2006, 2007) en De Vreese (2005).

Ook Beare (2009) analyseerde mediarespons rondom motorclubs. Een interessante observatie is dat motorclubs gebaat zijn bij veel media-aandacht, omdat het ze helpt aanzien te verwerven in het criminele circuit. En dat het de politie is die die aandacht faciliteert. Herhaaldelijk ziet Beare dat politie meer geweld en uitbreiding van territorium voorspelt. Berichtgeving betreft volgens haar voornamelijk de dreiging die uitgaat van outlaw motorclubs en veel minder hun concrete criminele activiteiten.

Toch vergt de aandacht die motorclubs in de media krijgen verdere nuancering dan dit eendimensionale narratief van 'badasses' en de behoefte aanzien te krijgen in de onderwereld. Hoewel er het nodige bekend is over de aard van de clubs en hun handelen (o.a. Barker, 2014; Grennan e.a., 2000; Goldsworthy \& McGilli- 
vray, 2017; Piano, 2017), is zelden onderzocht op welke manier de groep in het nieuws komt en nog minder op welke manier de stem van de club in het nieuws komt.

Recent onderzochten Andersen en Krumsvik (2017) beter onderbouwd de mediarepresentatie van Noorse motorrijders. Zij analyseerden naast krantenberichten ook posts op een Facebookpagina van Pay Back Norway, het officiële orgaan dat de rechten van motorrijders in Noorwegen en Zweden verdedigt. Zij concluderen dat het beeld van georganiseerde misdaad in de Noorse media dominant is en dat 'counter narratives' maar zelden in de gewone media doordringen. De bikers laten daarbij volgens Andersen en Krumsvik kansen onbenut om hun tegencultuur te presenteren door elementen te benadrukken als vriendschap, het buitenleven en de bijdragen die motorrijders leveren aan de samenleving. In termen van framingtheorie: ze zetten zelden een autonoom counterframe in.

Hoe zien we Nederlandse outlaw motorclubs gerepresenteerd in het nieuws? En wat zeggen ze als ze aan het woord komen? We hebben dit onderzocht via framinganalyse.

\section{Methode: framinganalyse}

Het doel van een (kwalitatieve) framinganalyse is inzicht te krijgen in de manier waarop media berichten over een maatschappelijk verschijnsel. Framinganalyse is een vorm van inhoudsanalyse. Inhoudsanalyse is gebaseerd op twee uitgangspunten: de idee dat media denkbeelden en normen uit de samenleving reproduceren en spiegelen, en de idee dat maatschappelijke problemen beter bestudeerd kunnen worden als sociale constructen dan als objectief waarneembare entiteiten (Potter \& Kappeler, 2006; Best, 2008). Media spelen in dat constructieproces een cruciale rol: ze vormen voor een groot deel van het publiek de belangrijkste bron van kennis, zeker wanneer het misdaad betreft zoals die van motorbendes. Dit onderzoek gaat dus over mediarepresentatie en niet over misdaadstatistieken.

Naast dit theoretische vertrekpunt impliceert framinganalyse ook een specifieke manier van inhoudsanalyse van mediaberichten. Van Gorp (2007) beschrijft dat als een inductieve analyse in vijf stappen. De analyse begint met het verzamelen van teksten. Vervolgens worden daarin typerende tekstuele en visuele elementen ('framing devices') geïdentificeerd en voorzien van codes ('open codering', vgl. Van Gorp, 2006, 104). Het gaat daarbij om zaken als woordkeuze, beelden, metaforen, exemplarische gebeurtenissen, enzovoort. In een derde fase - 'axiaal coderen' - wordt gezocht naar patronen in deze inventaris: de elementen die samen een frame vormen. De codes worden ondergebracht in dimensies of 'assen' van een aantal discourslijnen of gehelen van samenhangende vertogen. Samengevat komt dat in ons geval neer op een inventarisatie van de wijze waarop het probleem gedefinieerd wordt, waar precies de oorzaak en de oplossingsrichting worden gezien en wat de morele basis is om het als probleem te bestempelen (de zogenaamde 'reasoning devices'). De vierde stap is het selectieve coderen en - wat Van Gorp noemt - de emanatie van frames. Er wordt daarbij gezocht naar clusters 
die het omvattende denkbeeld het best weergeven. Tot slot wordt in een geschiktheidstoets nagegaan hoe plausibel de gevonden frames zijn.

De resultaten van een framinganalyse van mediamateriaal worden samengevat in een framingmatrix, die het materiaal terugbrengt tot een beperkt aantal categorieën die samen het verschijnsel in kaart brengen (zie bijlage 1). In de matrix wordt een aantal frames benoemd en worden per frame naast de framing devices ook reasoning devices in kaart gebracht, dat zijn de argumentatieve beweringen waarmee het probleem wordt gedefinieerd, de oorzaak en de oplossingsrichting.

Daarbij gaat het om het in kaart brengen van dominante frames en niet om een tot in detail uitputtende opsomming van alle vigerende bijdragen aan het discours. Door middel van open codering worden in de eerste analyseronde de te onderzoeken teksten opgebroken in verschillende reasoning devices. Die bestaan onder andere uit de manier waarop het probleem gedefinieerd wordt, wat als oorzaak wordt gezien, wat als morele basis, wie er verantwoordelijk wordt gehouden, en in welke richting de oplossing moet worden gezocht.

In het resultaat van de analyse vindt men dus een beperkt aantal samenvattingen van dominante frames. Die geven geen volledige weergave van de 'werkelijkheid' van het discours, maar scheppen daarin wel ordening en bieden inzicht.

Uit de database LexisNexis ${ }^{3}$ zijn uit de periode 1990 tot 2014 door middel van trefwoorden bijna 17.000 krantenberichten over motorclubs geselecteerd. ${ }^{4}$ Daarvan gingen er uiteindelijk 11.000 over outlaw motorclubs. Voor het voorliggende onderzoek is uit dat nieuws een corpus geselecteerd van 790 berichten met artikelen waarin leden van de motorclubs zelf aan het woord komen. Deze data zijn geanalyseerd met behulp van een framingmatrix (vgl. Van Gorp, 2006). De framinganalyse geeft structuur aan de inhoudsanalyse, in die zin dat de resultaten geordend worden in samenhangende mediaframes en niet in bijvoorbeeld losse thema's of tropen.

In onze analyse blijven andere nieuwsmedia (radio, tv) en sociale media buiten beschouwing. Dit is deels een pragmatische keuze: tekst in krantenberichten levert handzaam en zeer rijk te onderzoeken materiaal op over een langere periode. Een theoretische overweging is daarnaast dat er een hoge graad van zelfreferentie bestaat tussen verschillende media, in die zin dat mediaboodschappen doorgaans verwijzen naar andere vergelijkbare of identieke mediaboodschappen of gebeurtenissen (vgl. Thompson 1995, 110-111). De resultaten van de inhoudsanalyse worden samengevat in een framingmatrix.

3 In de database LexisNexis zijn alle Nederlandse nationale en regionale dagbladen doorzocht inclusief hun webpagina's en berichten van omroepen en tijdschriften. Een lijst daarvan is te vinden in LexisNexis onder 'all Dutch news'.

4 Met dank aan masterstudenten van de opleiding Criminologie en de opleiding Journalistiek en Nieuwe Media van de Universiteit Leiden. Zie resp. Bakker, 2017; Schutte, 2016; Witsen, 2016; Dekker, 2015. 


\section{Resultaten}

De kwalitatieve analyse van de krantenberichten toont twee duidelijk te onderscheiden frames. Een waarin outlaw motorgangs worden voorgesteld als een vorm van georganiseerde misdaad en een - minder prominent - counterframe waarbij met name de mediarepresentatie als kern van het probleem wordt gepresenteerd. Merk op dat geen van beide frames de werkelijkheid afdekt: dat is immers niet de inzet van een framinganalyse. Wel geven beide frames als grof geborstelde samenvatting inzicht in de structuur van de maatschappelijke discussie over het verschijnsel.

Het eerste is het frame dat gesponsord wordt door partijen die in de nieuwsmedia over dit onderwerp het vaakst aan het woord komen: justitie en politie. Die schetsen het probleem als iets waarbij de kern niet de delicten op zich betreft, maar het feit dat het hier gaat om georganiseerde misdaad, om delicten die worden gepleegd in groepsverband. De morele basis onder het probleem is het feit dat georganiseerde misdaad een bedreiging vormt voor de democratie, en de oplossing ervan wordt dan ook gezocht in het aanpakken van juist dat clubverband. Vooral dit aspect van georganiseerdheid in groepsverband in combinatie met het benadrukken van het feit dat het om substantiële aantallen gaat, om een overmacht die voor de politie te groot is, dat er veel clubs zijn en dat het aantal toeneemt, maakt het probleem voor nieuwsmedia relevant en in de ogen van het publiek beangstigend. De gepresenteerde oplossingsrichting in dit frame is dan ook het uiteendrijven, ontmoedigen of verbieden van de clubs. We zien het frame gerepresenteerd in termen als 'wijdverbreid', 'internationaal', 'Europees', 'de vermenging van legale en illegale geldstromen' en de 'verweving van de onder- en bovenwereld'. Ook het consequent vermelden van de clubaffiliatie wanneer een afzonderlijk clublid betrokken is bij een incident of delict kan gezien worden als middel om dit georganiseerde-misdaadframe te versterken. Typerend voor dit frame zijn de volgende twee voorbeelden. In het eerste zien we het aspect van de grote internationale organisatie verwoord, in het tweede de angst voor vermenging van onder- en bovenwereld:

'Volgens de Canadese journalisten Julian Sher en Bill Marsden, die in 2003 het boek The Road to Hell over de bendeoorlogen publiceerden, kan de politie complete afdelingen van de Hells Angels oprollen zonder dat de club noemenswaardig aan kracht inboet. "Hells Angels beschikken over het beste van twee werelden, een nationaal en een internationaal netwerk waarin samenwerkingsverbanden kunnen worden aangegaan, zonder de nadelen van een strakke piramide-achtige structuur. In dat opzicht lijken ze op terreurcellen van Al-Qaeda. Maar de terroristen kunnen van de Angels nog heel wat opsteken."' (Apeldoornse Courant, 10 november 2006)

'De horeca-afpersing is volgens Justitie een klassiek voorbeeld van vermenging van onder- en bovenwereld die de samenleving ondermijnt.' (AD/Amersfoortse Courant, 12 april 2012) 
Tegenover dit criminaliserende frame van justitie en politie zetten clubs en hun leden in interviews, in reacties op gebeurtenissen en in zelf georganiseerde events, zoals de genoemde persconferentie, een counterframe in de markt. Hierin is de kern van het probleem de representatie door justitie en media. Als justitie haar werk eerlijk zou doen en journalisten zouden daar eerlijk over berichten, dan zou er geen probleem zijn. De gepresenteerde oplossingsrichting is dan ook dat nieuwsmedia ophouden met het verspreiden van 'leugens' en dat de politie en justitie stoppen met het verspreiden van 'onware verhalen', met de 'hetze' tegen de motorclubs. Als morele basis worden principes van de Nederlandse rechtsstaat aangehaald, zoals het recht op gelijke behandeling en de onschuldpresumptie:

'Sprookjes van Grimm. Als justitie op zulke praatjes afgaat, kan je langzamerhand half Nederland wel opsluiten. Alsof de Hells Angels een stelletje barbaren zijn, 't is gewoon een motorclub.' (De Telegraaf, 25 januari 2003)

'Het is een schande dat duizenden bolletjesslikkers niet worden vervolgd, terwijl een lid van een motorclub - die zich keurig aan de regels houdt - wordt aangepakt.' (Big Willem, president van de Hells Angels; Het Parool, 30 januari 2002)

'Ons huidige imago is in de loop der jaren echter door de media en justitie gecreëerd. Ik heb duizend keer gezegd dat wij een motorclub zijn, we houden bikeshows en die Tattoo Convention, maar brengen ook speelgoed naar kankerpatiëntjes en staan bloed af.' (Leeuwarder Courant, 19 mei 2007)

Typische middelen die dit frame representeren, zijn woorden als 'leugens', 'sprookjes', verwijzingen naar het recht en het benadrukken van onschuld. Dit counterframe is niet-autonoom, het refereert aan het negatieve frame en triggert het daarmee ook.

Maar behalve het ingaan tegen het heersende beeld en het beschuldigen van pers en justitie, wordt dit frame ook verder ingevuld met een concreet tegenbeeld. Het is dus meer dan het ontkennen van het georganiseerde-misdaadframe. Dat counterframe is dat van een gezellige club, van mannen met een hobby. Verder wordt de club nogal eens als een hechte familie gepresenteerd met leden die voor elkaar opkomen:

" $t$ Is voor de gewone burger misschien moeilijk te begrijpen, maar de club gaat voor alles!' (De Telegraaf, 15 januari 2003)

Daarbij wordt geregeld verwezen naar een erecode van de broederschap, wederzijds respect, loyaliteit en eerlijkheid. Typerende voorbeelden die dit laten zien, zijn:

'Het onderzoek is niet eenvoudig geweest. De opgepakte Nomads houden zich vrijwel allemaal aan de erecode die onder Hells Angels geldt: je praat niet met de politie.' (Eindhovens Dagblad, 27 januari 2005) 
'Mensen hebben behoefte aan de broederschap die bij ons heerst. Ze zijn helemaal klaar met de overheid en zien dat wij er een vrijere levensstijl op nahouden.' (Provinciale Zeeuwse Courant, 10 april 2014)

"'Dit druist in tegen de normen en waarden waar de club voor staat," reageert Ruperti. "Daarom is er direct besloten om de twee uit de club te zetten." De Demons benadrukken dat de hennepplantages niets met clubactiviteiten te maken hebben.' (AFD, 8 februari 2014)

Hoewel de clubs wortelen in ideeën over anarchie en anti-establishment en gekarakteriseerd worden als tegencultuur, zijn de normen en waarden die spreken uit de krantenberichten, mediaoptredens en ook uit de websites waarmee de clubs zich presenteren, zeer traditioneel te noemen (Wood, 2003; Montgomery, 1976; Austin e.a., 2010). Bij deze zelfpresentatie horen ook optredens zoals toy runs voor ziekenhuizen - media-events of pseudo-events (Boorstin, 1961; Dayan \& Katz, 1996; Nimmo \& Combs, 1983; Scherer, 2008) -, gebeurtenissen speciaal gericht op media-aandacht die, zorgvuldig georkestreerd, dienen om het imago vorm te geven.

Herhaaldelijk zien we dit 'mannen met een hobby'-frame terug in artikelen waarin leden 'het ware verhaal' vertellen en het gezellige clubverband benadrukken:

'En ook bij de Hell's Angels zijn jongens die bij gemeenten werken. We zijn gewoon mannen die van motoren houden en van gezelligheid. $\mathrm{Nu}$ vertrekken er leden vanwege de politieacties.' (Marcel en Henny van Motorclub Black Sheep; De Gelderlander, 21 maart 2015)

'Volgens de No Surrender-leden worden ze ten onrechte in de criminele hoek gezet. In december vertelden ze in een RTL-reportage van misdaadjournalist John van de Heuvel dat No Surrender een "multiculti-motorclub is, waar het klikt als een gek". Volgens het voormalige Hells Angels-lid Willem van Boxtel is er "veel gezelligheid en gaan ze lekker met zijn allen rijden".' (de Volkskrant, 23 januari 2014)

Maar in dit benadrukken van het clubaspect en maatschappelijke dienstverlening schuilt een gevaar voor de clubs. De publieke opinie kan immers doorslaan naar de andere kant en het publiek kan gaan geloven dat de outlaw motorclubs echt niets anders zijn dan een Rotary Club die toevallig op motorfietsen rijdt in plaats van in SUV's.

\section{Geloofwaardigheid}

Bovendien is het soms - na evident uit de hand gelopen openbare optredens moeilijk om dit 'mannen met een hobby'-frame nog geloofwaardig te promoten. Desgevraagd nuanceren clubleden dan het frame. In ons materiaal vonden we onder andere de volgende mitigerende beelden. In plaats van het veelvuldig gebruikte 'wij zijn geen criminele organisatie', vinden we hier varianten op, zoals: 
'Ik heb niet voor dominee gestudeerd.' (Het Parool, 31 mei 2005)

'We zijn als motorclub natuurlijk geen koorknapen of zachtgekookte eieren.' (Algemeen Dagblad/Haagse Courant, 16 april 2014)

'We zijn geen padvinders.' (Dagblad van het Noorden, 7 februari 2012)

Met deze retorische strategie wordt het counterframe van de gezellige club versterkt op een manier die imagotechnisch een risico inhoudt. Het oproepen van beelden van dominees, koorknapen en padvinders kan ertoe leiden dat nieuwsconsumenten dat blijvend gaan associëren met de clubs en het gewenste beeld van ruige motorclub te zeer naar de achtergrond verdwijnt.

Het lijkt erg op een bekende retorische strategie, die erop neerkomt dat eerst iets wordt toegegeven, om vervolgens iets anders te ontkennen. Bijvoorbeeld: 'Ja, er vallen hier wel eens klappen, maar mensen doodslaan, dat hebben we nog nooit gedaan.' Of: 'We roken wel eens een jointje, maar in drugs handelen, dat doen we niet.' De spreker hoopt dat de openheid en eerlijkheid van de eerste bewering afstralen op de tweede. De klassieke retorische term ervoor is concessio (Mann \& Thompson, 1988; Szczyrbak, 2015). Omdat het eerste lid van de concessio vaak refereert aan iets triviaals, wordt deze retorische zet geacht de geloofwaardigheid van de spreker te vergroten.

Toch heeft de concessio in deze vorm een belangrijk risico in zich, namelijk dat de nieuwsconsument toch alleen het opgeroepen negatieve beeld onthoudt: mensen doodslaan, drugshandel. En als die associatie eenmaal is gelegd, dan valt die moeilijk te dissociëren. En dat kan ertoe bijdragen dat toch het criminele frame prominent blijft.

Een beter pr-advies is daarom om na de concessie (er wordt wel eens wat bier te veel gedronken, we rijden wel eens door rood) onmiddellijk het clubframe te activeren en te benadrukken dat de motorclub een club is die vooral ten doel heeft gezelligheid te bevorderen. Toenmalig Hells Angels president Willem van Boxtel had dat goed in de gaten, toen hij in Het Parool reflecteerde op de begrafenis van aspirant-lid Sam Klepper:

'Het was een beetje luidruchtig misschien, maar wij brengen iemand op gepaste wijze naar het graf en iedereen heeft opeens een mening. Waarom maakt men zich zo druk over een motorclub? We hebben een vrije levensstijl, we houden van feestvieren, wat is daar verkeerd aan?' (Het Parool, 13 februari 2001)

Zolang justitie geen club veroordeeld heeft, kan dit een effectieve en geloofwaardige manier zijn om de representatie in de Nederlandse media bij te sturen. Referenties aan criminele handelingen én referenties aan koorknapen moeten daarbij achterwege blijven: dergelijke referenties activeren immers ofwel het reactieve counterframe, ofwel een nieuw zelfstandig (en ongewenst) frame. 


\section{Conclusie}

Hoewel deze analyse is gebaseerd op berichtgeving als resultante van het nieuwsselectieproces dat eraan voorafgaat, lijkt de conclusie gerechtvaardigd dat clubs er een mediastrategie op na houden. Omdat het beeld dat kranten van de clubs schetsen het risico in zich heeft door te slaan naar de zachte kant, kan het soms nodig zijn om 'reparerende' strategieën in te zetten. Het bestudeerde materiaal geeft tal van voorbeelden van dergelijke strategieën.

Mitigerende strategieën die het al te zachte karakter van de clubs moeten aanpassen aan de (media)werkelijkheid lijken argumentatief een sterke zet. Ze nuanceren niet alleen het beeld, maar lijken ook het vermogen te hebben om de geloofwaardigheid van de afzender te vergroten: wie toegeeft dat niets menselijks hem vreemd is, moet je geloven als hij daaraan toevoegt geen crimineel te zijn.

Daarmee wijken onze resultaten af van die van de vergelijkbare studie van Andersen en Krumsvik (2017). In Nederland lijkt het frame van de tegencultuur veel beter door te dringen tot de mainstreammedia dan in Noorwegen. Andersen en Krumsvik concluderen dat daardoor in Noorwegen het frame van georganiseerde misdaad dominant blijft. Saillant is daarbij dat de club die de motorrijders vertegenwoordigt - PayBack Norway - een genuanceerde kijk op de clubs in de weg staat. Volgens Andersen en Krumsvik refereert PayBack voortdurend aan motorrijders als een collectief en bespreekt deze hoogst zelden de feiten rondom individuele criminele cases. Op die manier, zo concluderen Andersen en Krumsvik, doen ze geen goed aan de zaak, door een veel homogenere groep te lijken dan ze in werkelijkheid zijn. Dat is dus heel anders dan in Nederland, waar juist dit narratief - het gaat om individuele leden en niet om de club - de inzet van veel mediaoptreden vormt. (Dat narratief maakt in onze analyse deel uit van het counterframe, maar vormt als element geen nieuw zelfstandig frame.)

\section{Discussie}

De opzet van dit onderzoek is beperkt tot nieuws uit kranten zoals dat is opgenomen in de database van LexisNexis. Er zijn echter andere bronnen van beeldvorming die een uitbreiding kunnen vormen op het hier uitgevoerde onderzoek. Een belangrijke bron vormen sociale media zoals Facebook en Twitter en de websites van de clubs. Een vervolgonderzoek naar de wijze waarop de clubs dergelijke media inzetten om hun imago vorm te geven, lijkt daarom een waardevolle aanvulling.

Daarnaast is deze studie het resultaat van kwalitatief onderzoek naar mediarepresentatie. Dergelijk onderzoek doet uitspraken over categorieën en de middelen die gebruikt worden. Wat niet onderzocht is, is de omvang van die categorieën (hoe vaak komt dat dan voor?). Daarvoor zijn andere methoden geëigend, zoals kwantitatieve inhoudsanalyse om na te gaan hoe vaak en op welke momenten de clubs de media opzoeken. Zo valt bijvoorbeeld op dat bepaalde clubs veel vaker in de media figureren dan andere en dat bepaalde beelden vaker dan andere in het nieuws komen. Ook over het evenwicht in berichtgeving kan dergelijk kwantita- 
tief onderzoek resultaten opleveren. Een andere belangrijke vraag is waarom en met welke afwegingen clubs media inzetten. Daarvoor is etnografisch onderzoek naar mediastrategieën nodig.

Ook doet dit onderzoek geen uitspraak over de publieksperceptie van de clubs. Bij kwalitatieve inhoudsanalyse vormt die invloed een vertrekpunt (die bepaalt immers de relevantie van de analyse). De denkbeelden bij het publiek vallen echter buiten ons blikveld.

Deze kwalitatieve analyse van krantenberichten tussen 1990 en 2014 laat zien dat er twee tamelijk eenduidige frames bestaan waarmee de motorclubs in de media geportretteerd worden. Aan de ene kant is dat het frame dat gesponsord wordt door justitie en politie en dat de betrokkenheid bij georganiseerde misdaad benadrukt. Daartegenover staat een counterframe waarbij motorclubs en hun woordvoerders of advocaten als bron worden gebruikt. Dat frame vecht de beeldvorming door justitie en politie aan door de kenmerken van het 'gewone' clubleven en een reeks traditionele normen en waarden te benadrukken.

\section{Literatuur}

Andersen, U.C. \& Krumsvik, A.H. (2017). Talking back: Bikers' mediated self-representation. International Journal of Motorcycle Studies, 13. Geraadpleegd op 21 juni 17 via motorcyclestudies.org/volume-13-2017/talking-back-bikers-mediated-self-representation-unn-conradi-andersen-arne-h-krumsvik/.

Austin, D., Gagné, P. \& Orend, A. (2010). Commodification and popular imagery of the biker in American culture. The Journal of Popular Culture, 43(5), 942-963.

Bakker, S. (2017). Alles wat Onze Lieve Heer en de majesteit verboden heeft. Een onderzoek naar de framing van outlaw motorcycle gangs in Nederlandse kranten. MA thesis Universiteit Leiden.

Barger, S. (2001). Hell's Angel: The life and times of Sonny Barger and the Hell's Angels motorcycle club. New York: Harper Collins.

Barker, T. (2007). Biker gangs as organized crime. Cincinnati, OH: Anderson.

Barker, T. (2014). Outlaw motorcycle gangs as organized crime groups. Cham, Heidelberg, New York, Dordrecht, London.

Beare, M.E. (2009). PowerPoint lecture: Moral panics and 'exceptional crimes'.

Beare, M.E. \& Hogg, C. (2013). Listening in... to gang culture. Canadian Journal of Criminology and Criminal Justice, 55(3), 421-452.

Best, J. (2008). Social problems. New York, NY: WW Norton.

Blokland, A., Hout, L. van, Leest, W. van der \& Soudijn, M. (2017). Not your average biker: Criminal careers of members of Dutch outlaw motorcycle gangs. Trends in Organized Crime, 1-24.

Boorstin, D.J. (1961). The image, or, what happened to the American dream. London: Weidenfeld and Nicolson.

Castleberry, G.L. (2014). Revising the western: Connecting genre rituals and American western revisionism in tv's Sons of Anarchy. Cultural Studies $\leftrightarrow$ Critical Methodologies, 14(3), 269-278.

Cohen, S. (2002). Folk devils and moral panics: The creation of the mods and rockers. Hove, UK: Psychology Press.

Dayan, D. \& Katz, E. (1996). Media events: The live broadcasting of history. Cambridge, MA: Harvard University Press. 
Dekker, T. (2015). Motorbendes in de media: een casestudy naar het concept moral panic. MA thesis Universiteit Leiden.

Entman, R.M. (1993). Framing: Toward clarification of a fractured paradigm. Journal of Communication, 43(4), 51-58.

Ferrell, J. \& Sanders, C.R. (eds.) (1995). Cultural criminology. Boston: North Eastern University Press.

Fuglsang, R.S. (2003). Framing the motorcycle outlaw. In: S.D. Reese, O.H. Gandy Jr. \& A.E. Grant (eds.). Framing public life: Perspectives on media and our understanding of the social world. New York: Routledge, 185-194.

Gitlin, T. (1980). The whole world is watching. Mass media in the making and unmaking of the new Left. Los Angeles/London: University of California Press.

Goffman, E. (1959). The presentation of self in everyday life. New York: Anchor Books.

Goldsworthy, T. \& McGillivray, L. (2017). An examination of outlaw motorcycle gangs and their involvement in the illicit drug market and the effectiveness of anti-association legislative responses. International Journal of Drug Policy, 41, 110-117.

Grennan, S., Britz, M.T., Rush, J. \& Barker, T. (2000). Gangs: An international approach. Upper Saddle River, NJ: Prentice Hall.

Hayward, K.J. \& Young, J. (2004). Cultural criminology: Some notes on the script. Theoretical Criminology, 8(3), 259-273.

Heuvel, J. van den \& Huisjes, B. (2009). De gevallen engel: één man tegen de Hells Angels. Schelluinen: House of Knowledge.

Hobsbawm, E.J. (1971). Primitive rebels. Studies in archaic forms of social movement in the 19th and 20th centuries. Manchester: Manchester University Press.

Hobsbawm, E.J. (1972). Bandits. Harmondsworth: Penguin.

Jenkins, P. (1995). Clergy sexual abuse: The symbolic politics of a social problem. In: J. Best (ed.). Images of issues. Typifying contemporary social problems. New York: Aldine de Gruyter, 105-130.

Jenkins, P. (2001). Pedophiles and priests. Anatomy of a contemporary crisis. Oxford: Oxford University Press.

Katz, K. (2011). The enemy within: The outlaw motorcycle gang moral panic. American Journal of Criminal Justice, 36(3), 231-249.

Koetsenruijter, W. \& Burger, P. (2017). Institutional failure or individual perversity? Framing church abuse in the news in four European countries. Rhetoric and Communications E-Journal (29).

Kooistra, P. (1989). Criminals as heroes: Structure, power \& identity. Bowling Green: Bowling Green State University Press.

Kreemers, H.P.M. (2011). De 'Woodstock-defense' en seksueel misbruik van minderjarigen in de Nederlandse Rooms-Katholieke Kerkprovincie. In: W. Deetman e.a. (red.). Seksueel misbruik van minderjarigen in de Rooms-Katholieke Kerk. Uitgebreide versie deel 2: De achtergrondstudies en essays. Amsterdam: Balans, 149-155.

Lanjouw, J. \& Burger, P. (2013). Criminals as heroes. News media rhetoric in the Heineken kidnap case. In: H. Van Belle, P. Gillaerts, B. Van Gorp, D. Van de Mieroop \& K. Rutten (eds.). Verbal and visual rhetoric in a media world. Leiden: Leiden University Press, 289-307.

Lowe, M. (1988). Conspiracy of brothers. Toronto, ON: HarperCollins.

Lyng, S. \& Bracey, M. (1995). Squaring the one percent: Biker style and the selling of cultural resistance. In: J. Ferrell \& C.R. Sanders (eds.). Cultural criminology. Boston: North Eastern University Press, 235-276. 
Mann, W.C. \& Thompson, S.A. (1988). Rhetorical structure theory: Toward a functional theory of text organization. Text-Interdisciplinary Journal for the Study of Discourse, 8(3), 243-281.

McRobbie, A. (1994). Folk devils fight back. New Left Review, 203, 107-117.

McRobbie, A. \& Thornton, S.L. (1995). Rethinking 'moral panic' for multi-mediated social worlds. British Journal of Sociology, 46, 559-574.

Montgomery, R. (1976). The outlaw motorcycle subculture. Canadian Journal of Criminology and Corrections, 18, 332.

Nimmo, D. \& Combs, J.E. (1983). Mediated political realities. New York: Longman.

Piano, E.E. (2017). Free riders: The economics and organization of outlaw motorcycle gangs. Public Choice, 171(3-4), 283-301.

Potter, G.W. \& Kappeler, V.E. (2006). Constructing crime: Perspectives on making news and social problems. Long Grove: Waveland Press.

Presdee, M. (2000). Cultural criminology and the carnival of crime. New York: Routledge.

Roks, R. (2016). In de h200d. Doctoral dissertation Erasmus School of Law (ESL).

Roks, R. \& Staring, R.J.H.M. (2008). Crime, rhyme en de media: een eigentijdse levensgeschiedenis van een Haagse gangsta. In: F. Bovenkerk, D. Siegel \& F.V. van Gemert (red.). Culturele criminologie. Den Haag: Boom Juridische uitgevers, 161-173.

Scherer, H. (2008S Blackwell Publishing. Blackwell Reference Online, 20 June 2017, www. communicationencyclopedia.com/subscriber/tocnode.html?id=g9781405131995_ yr2015_chunk_g978140513199518_ss36-1.

Schlesinger, P. \& Tumber, H. (1994). Reporting crime: The media politics of criminal justice. Oxford: Clarendon Press.

Schutte, R.A. (2016). 'We worden ten onrechte gecriminaliseerd'. Een onderzoek naar het framegebruik van outlaw motorcycle gangs. MA thesis Universiteit Leiden.

Schutten, H., Vugts, P. \& Middelburg, B. (2004). Hells Angels in opmars: motorclub of misdaadbende? Utrecht: Monitor.

Sykes, G.M. \& Matza, D. (1957). Techniques of neutralization: A theory of delinquency. American Sociological Review, 22(6), 664-670.

Szczyrbak, M. (2015). Genre-based analysis of the realisation of concession in judicial discourse. Studia Linguistica Universitatis Iagellonicae Cracoviensis, 126(1), 127-148.

Thompson, J.B. (1995). The media and modernity: A social theory of the media. Stanford, CA: Stanford University Press.

Van Gorp, B. (2005). Where is the frame? Victims and intruders in the Belgian press coverage of the asylum issue. European Journal of Communication, 20(4), 484-507.

Van Gorp, B. (2006). Framing asiel: indringers en slachtoffers in de pers. Leuven: Acco.

Van Gorp, B. (2007). Het reconstrueren van frames via inductieve inhoudsanalyse: uitgangspunten en procedures. Kwalon, 35(12), 13-18.

Van Gorp, B. \& Vercruysse, T. (2012). Frames and counter-frames giving meaning to dementia: A framing analysis of media content. Social Science \& Medicine, 74(8), 1274-1281.

Vreese, C.H. de (2005). News framing: Theory and typology. Information Design Journal + Document Design, 13(1), 51-62.

Vries, P.R. de (1983). De zaak Heineken. Leiden: Batteljee en Terpstra.

Witsen, F. (2016). 'Wij zijn geen koorknapen, maar we zijn ook geen criminelen'. Imagomanagement van de Hells Angels Motorcycle Club Nederland in de media. Scriptie VU Amsterdam.

Wolf, D.R. (1991). The rebels: A brotherhood of outlaw bikers. Toronto, ON: University of Toronto Press.

Wood, J. (2003). Hell's Angels and the illusion of the counterculture. The Journal of Popular Culture, 37(2), 336-351. 
Bijlage 1: Framing matrix OMG's in Nederlandse nieuwsmedia.

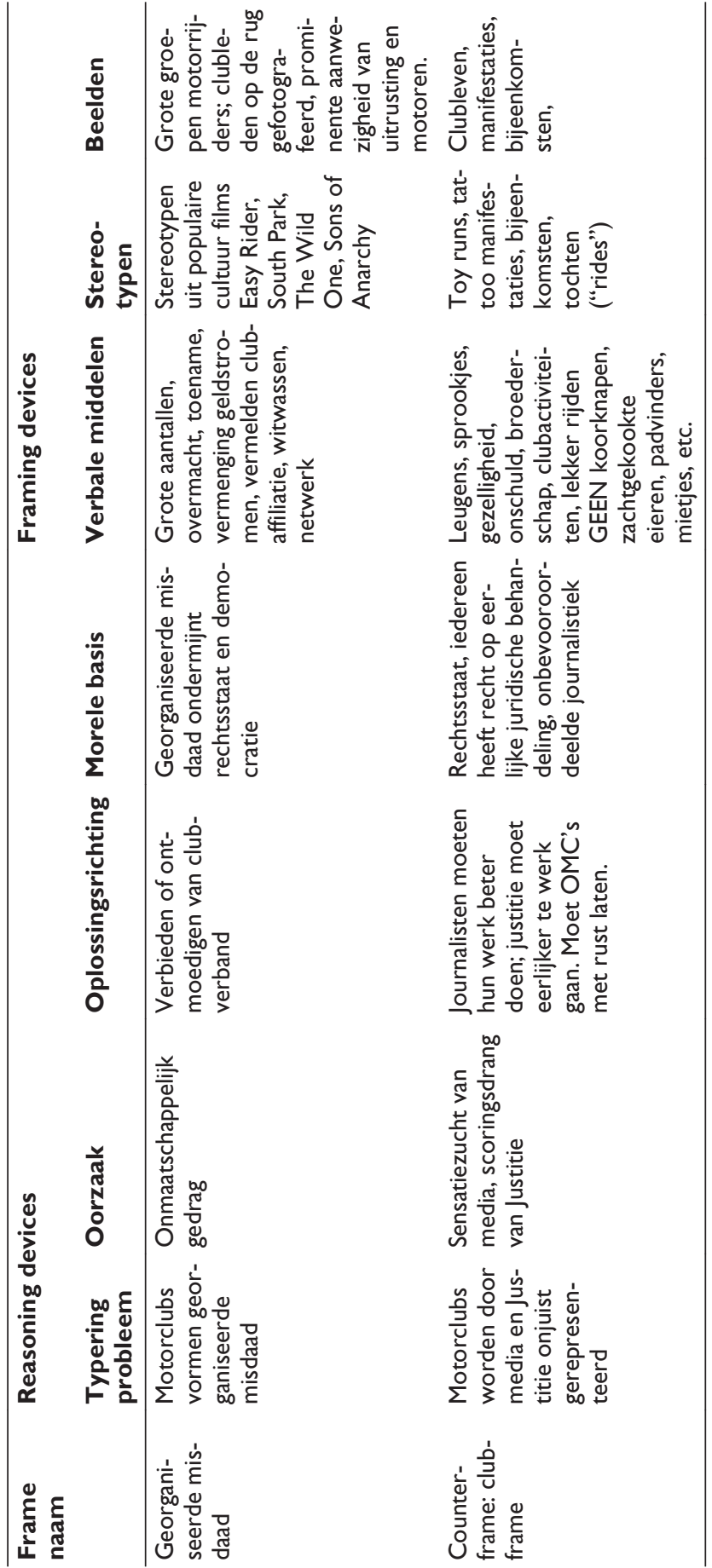

